\title{
새로운 글로벌 파트너십과 개발협력 역할에 대한 재고
}

\section{목 차}

I. 서론

II. 이론적 논의

1. ODA 행위주체의 변화

2. 협력구도의 전환

3. 남남협력 개념의 발전과정

III. 새로운 글로벌 파트너십에 대한 재고: 쿠바와 아이티 사례를 중심으로

1. 쿠바의 남남협력

2. 아이티에 대한 남남협력

\section{$\mathrm{IV}$. 결론}

\section{I. 서론}

Post-2015 체제에서 다루어지고 있는 지속가능한 발전목표(Sustainable Development Goals, 이 하 SDGs)는 17 개 목표와 169 개의 세부목표로 이루어져 있다. SDGs는 다차원적 관점에서 사회, 경제, 환경적 목표를 포괄적으로 접근하고 있다. SDGs가 논의되고 있는 오늘날 국제체제의 환경은 $\mathrm{MDGs}$ 수립 때와는 현저히 다르며 이처럼 SDGs의 세부목표는 국제체제의 변화양상을 반영하고 있다.

이와 같이 Post-2015 체제에서 '세계화의 효과' 가 확대되면서 영토를 초월한 국가 간 상호연결성 과 의존성이 강화되고 있다. 따라서 개발도상국들이 직면한 개발과제는 개발도상국 자체의 잘못된 구 조와 제도로부터 발생되고 있는 내부적이고 독립적인 문제가 아니며 다른 국가들의 정책과도 연관되 
고 있다. 이와 더불어 금융위기, 기후변화, 인구증가, 도시화, 식량 및 에너지 위기 등 글로벌 과제들 과의 연계성을 고려하고 이를 통해 해결해야 하는 다양한 의제들이 등장하고 있다.

따라서 이러한 변화의 흐름에 따라 부산세계개발원조 총회 이후 새로운 개발협력 체제에서 강조 되고 있는 원칙은 '포괄적인 파트너십' 의 확대이며 이러한 포괄적인 파트너십을 구현하기 위한 이행 수단으로 남남협력(south-south cooperation) $)^{1)}$ 이 지속적으로 논의되어 왔다. 남남협력 체제 내에 서 공여국과 수원국의 관계는 수평적이며 상호보완적이다. 또한 남남협력은 수원국의 주인의식, 개발 요구와 문화적인 다양성을 좀 더 적극적으로 반영할 수 있고 수원국의 제도적인 역량을 개선할 수 있 다는 점에서 전통적인 남북협력을 보완할 수 있는 효과적인 방안으로 부각되었다(정상희, 2013: 81; Rojas, 2011: 35). 이처럼 국내에서 남남협력에 대한 관심이 확대되면서 라틴아메리카에서 남남협력 을 적극적으로 활용하기 위한 방안을 모색하는 연구가 진행되었다. ${ }^{2)}$

그러나 현재 신흥공여국(emerging donors) 주도로 이루어지고 있는 남남협력은 장학금 지급, 공 동연수, 단기 전문가 파견, 세미나 등 기술협력 형태로서 모니터링과 평가 체제를 구축하기 어려우며 수행기관의 경험과 제도적인 역량이 부족하여 시간과 행정비용의 측면에서 부정적인 영향을 야기할 수 있다는 비판적인 시각이 제기되었다. 따라서 사업수행 기관에서 때때로 남남협력은 이상적인 수단 으로 간주되고 있으며 이를 회의적으로 바라보는 시각도 존재하고 있다.

그렇다면 남남협력은 글로벌 파트너십 체제를 구축하고 활성화하고자 하는 현재의 추세에 부합하 기 위해 유행처럼 언급되고 있는 이상적인 수단에 불과한 것일까? 왜 국제사회에서 남남협력에 대한 활용과 확대에 대해 지속적으로 논의되고 있는 것일까?

본 연구는 이러한 논점을 중심으로 2장에서 국제환경과 개발협력 체제에서 나타나고 있는 다양한 변화양상을 새롭게 출현한 행위주체와 이들 간 형성되고 있는 협력구도를 중심으로 분석하고자 한다. 남남협력에 대한 개념을 정립하고 이를 활용하는 방안과 관련하여 이현주(2009)와 정지원 외(2011) 등 기존 연구가 있으나 본 연구에서는 국제체제의 변화과정에서 특히 남남협력 개념의 발전과정에 초 점을 두고 분석하였다. 특히, 새로운 행위주체, 행위주체 간 협력구도, 이들 간의 형성되고 있는 포괄 적인 파트너십에 초점을 두고 남남협력의 개념을 재정립하였다.

3장에서는 새로운 글로벌 파트너십에 대해 재고하기 위해 공여국의 역할을 담당하고 있는 쿠바와 수원국의 입장인 아이티의 남남협력 사례를 분석하였다. 쿠바는 혁명 이후 사회주의적인 이념과 결

1) 본 연구에서는 이베로아메리카 사무국(SEGIB)의 정의에 따라 남남협력을 개발도상국 간의 기술협력으로 정의하고 자 한다(정상희, 2013: 87).

2) 경회대학교 산학협력단, 국제학연구원, 2015 출간예정. 『중남미지역 삼각협력 발전방안 연구」. 한국국제협력단. 
합된 평등주의적 성격의 교육제도가 수립되었으며 이러한 제도를 통해 배출된 의료 인력과 교사들은 전 세계 개발도상국에 파견되어 개발도상국에 대한 지원을 적극적으로 추진하였다. 쿠바는 1961년 미 국과의 단교 이후 2014년 미국과 국교 정상화를 선언했는데 이로 인해 최근 주목받고 있다. 아이티는 라틴아메리카 ‘남남협력의 실험실’로 비유될 정도로 전통공여국 뿐 아니라 라틴아메리카의 다양한 신 흥공여국들로부터 지원받고 있다.

4장 결론에서는 새로운 개발협력 이행수단과 관련하여 앞에서 분석한 쿠바와 아이티의 사례를 통 해 한국에 대한 정책적인 함의를 도출하고 향후의 개발협력체제에서 개발협력 개념과 역할을 재고하 면서 본 글을 마무리하였다.

제I장

\section{ODA 행위주체의 변화}

'세계화(globalization)'는 우리로부터 멀리 떨어져 있는 곳에서 발생하는 사건과 그곳에서 이루어 지는 정책결정에 의해 우리의 삶이 형성되어 가는 것을 의미하며 이처럼 세계화로 인해 상호연결성의 복합적인 망이 등장하고 있다(Heywood, 2013: 10).

오늘날 국제정치에서 흔히 논의되고 있는 '세계화의 효과'로 인해 영토적인 국경의 중요성은 줄어 들고 있으며 지방, 지역, 국제, 글로벌적 사건들은 지속적으로 상호작용하고 있다(Heywood, 2013: 10). 이러한 행위주체 간 상호의존과 연결성 효과는 국제개발협력 체제에서 확대, 심화되고 있으며 이 와 더불어 식량, 에너지, 금융위기, 기후변화 등 새로운 글로벌 과제가 대두되고 있다. 따라서 개별 국가는 다양한 정책분야에서 등장하고 있는 글로벌 과제에 효과적으로 대처할 수 없으며 이에 비국 가 행위자들과 국제기구의 수, 권한이 지속적으로 증가하고 있다. 이러한 과정에서 권력은 국가를 떠 나 분산되면서 자발적이며 지속적으로 협력하는 글로벌 거버넌스라라는 새로운 체제가 형성되고 있다 (Heywood, 2013: 457-460).

이러한 흐름 속에서 개발협력은 개발도상국의 경제, 사회분야에서 성장을 달성하고 발전을 이루기 위한 효율적인 수단이라는 목적을 넘어서 행위주체 간 포괄적인 협력을 통해 지속가능한 발전과 초국

3) 글로벌 거버넌스의 개념은 공적인 차원과 사적인 차원에서 개인과 기구들이 공동의 문제를 해결하기 위한 다양한 방식을 집약한 것이며, 충돌하고 있는 서로 다른 이익들을 조화시키며 협력적인 활동을 모색하는 지속적인 과정으 로 정의할 수 있다(Karns \& Mingst, 2009: 4). 
경적인 다양한 글로벌 과제를 해결하기 위한 효율적인 수단으로 고려되고 있다(정상희, 2015: 104105). 이외에도 개발협력은 "발상이나 생각의 직접적인 전달(direct transmission of ideas)"이 아닌 “문화적 공유의 지평(a shared cultural horizon)" 혹은 “국제적인 교류와 이동을 운영하는 도구”로 서 우리는 행위주체 간 관계(relationship)에 초점을 둘 필요가 있다(Chisholm, 2009: 4; Samoff, 2009: 125). ${ }^{4)}$

국제체제의 변화와 관련하여 언급할 수 있는 또 다른 특징은 OECD 내 개발원조위원회(DAC)의 전 통적인 공여국 역할과 비중이 감소하고 신흥공여국(emerging donor) ${ }^{5}$, DAC 비회원국(non-DAC Donor), 민간부문(private sector) 등 새로운 행위 주체의 역할이 확대되면서 다국 간 협력체제가 형 성되고 있는 것이다(정상희, 2015: 104). 따라서 시민사회, 기업, 민간재단 등 독립적이며 자율적인 비국가 행위자의 역할이 확대되고 있으며 이들은 Post-2015 체제에서 강조하고 있는 개발협력 재원 조성과 관련하여 중요한 역할을 담당할 전망이다.

이처럼 부산세계개발원조 총회와 Post-2015 체제에서 지속적으로 강조하고 있는 '포괄적인 파트 너십'을 통한 개발협력의 이행수단이란 국제환경의 변화와 다각화된 행위주체의 출현에 따라 이들 간 형성되고 있는 조정과 포괄적인 협력 체제를 통해 이루어지는 새로운 지원 방식을 의미한다고 볼 수 있다.

\section{2. 협력구도의 전환}

개발협력 체제에서 공여국과 수원국의 관계는 수평적인 구도로 변화하고 있으며(정상희, 2015: 108) 이와 관련한 대표적인 지원방식은 남남협력이다. 전통적이고 규범적인 개발협력체제에서 공여 국은 $\mathrm{DAC}$ 회원국을 지칭했으며 이와 대비되는 개념은 경제, 사회발전의 정도가 낮고 공여국으로부 터 개발협력을 지원받고 있는 수원국이다. 따라서 UNDP 등 국제기구에서 남남협력은 정치, 경제, 사 회, 문화, 기술 분야에서 두 개국 혹은 그 이상 개발도상국간의 양자(bilateral), 지역(regional), 소지 역(subregional), 지역 간(interregional) 수평적인 협력관계로서 행위주체 간 필요로 하는 재원, 기 술, 경험 등을 서로 제공하고 공유하는 협력행위로 정의할 수 있다(정상희, 2013: 85). 그러나 오늘날

4) "Foreign Aid can be understood as a tool, or set of tools, for managing international transfers and exchanges” (samoff, 2009: 125).

5) DAC에 의하면 신흥공여국은 비교적 최근 개발협력 프로그램 지원에 참여한 국가들이며 대부분 유럽연합 (European Union)의 회원국이다. 이들은 냉전 당시 원조를 지원했으나 시장경제로의 전환기에 원조를 지원 받 았다. 이들 국가들은 다른 개발도상국에서 개발협력 프로그램을 추진할 수 있는 법, 제도적인 체제를 구축했으 며 OECD 회원국과 비회원국 등이 포함되어 있다. OECD DAC, http://www.oecd.org/dac/45361474.pdf(검색일: 2015. 8. 31.) 
‘남남협력'의 행위주체에는 개발협력체제에서 지칭되었던 개발도상국이라는 수동적인 행위주체의 개 념으로부터 확대된 의미를 함축하고 있다.

본 연구에서는 행위주체 간 역할과 관계, 재원의 성격, 지원의 효과라는 분석요소에 초점을 맞추어 남남협력의 특성을 분석하고 역사적인 발전과정을 재고함으로써 발전하고 있는 남남협력의 개념을 재 정립하고자 한다. ${ }^{6)}$

\section{〈표 1〉남북협력과 남남협력}

\begin{tabular}{l|l|l}
\hline \multicolumn{1}{c|}{ 구분 } & \multicolumn{1}{c|}{ 남북협력 } & \multicolumn{1}{c}{ 남남협력 } \\
\hline 행위주체 & $\begin{array}{l}\text { 최소한 소득수준이 높거나 DAC } \\
\text { 공여국 개입 }\end{array}$ & 개발도상국, 중소득국, 신흥경제국 \\
\hline $\begin{array}{l}\text { 행위주체자의 역할과 } \\
\text { 행위주체 간 관계 }\end{array}$ & $\begin{array}{l}\text { 공여국과 수원국, 수직적인 구도, } \\
\text { 일방적인 전달 }\end{array}$ & 수평적 구도, 상호협력, 교류 \\
\hline 주요한 협력행위 & 원조 & $\begin{array}{l}\text { 기술협력(정책전수, 전문가파견, } \\
\text { 재정적인 지원) }\end{array}$ \\
\hline 재원성격 & Top down방식이며 조건부 지원 & $\begin{array}{l}\text { 수원국의 요구와 필요에 부합하는 } \\
\text { 비조건성 지원 }\end{array}$ \\
\hline 효과 & 관료주의, 높은 행정비용 & $\begin{array}{l}\text { 신속한 집행, 낮은 행정비용, 수혜자에 } \\
\text { 대한 직접적인 효과 }\end{array}$ \\
\hline
\end{tabular}

출처: 정상희(2014)를 활용하여 재작성

전통적인 남북협력의 구도에서는 최소한 소득수준이 높은 국가 혹은 $\mathrm{DAC}$ 공여국이 행위주체자로 서 역할하고 있다. 반면에 DAC에 의하면 남남협력의 행위주체는 개발도상국, 중소득국, 신흥경제국 을 포괄하고 있으며 이들은 다른 개발도상국을 대상으로 정책전달, 전문가 파견, 재정적 지원 등 기술 협력을 통해 지원하고 있다. ${ }^{7)}$ 브라질, 중국, 인도, 남아프리카, 콜롬비아, 이집트, 태국, 칠레, 멕시코 등은 남남협력의 주요한 행위자로 볼 수 있다. ${ }^{8)}$

6) Runde, Daniel, "The new role for non-state actors in development: implications for communications officers", http://www.oecd.org/development/pgd/41769582.pdf(검색일: 2015. 8. 31.)

7) OECD DAC, http://www.oecd.org/dac/45361474.pdf(검색일: 2015. 8. 31.)

8) OECD DAC, http://www.oecd.org/dac/45361474.pdt(검색일: 2015. 8. 31.) 
남북협력에서 참여주체 간 역할과 관계는 공여국이 수원국에게 일방적으로 지원 혹은 전달하는 수 직적인 성격의 구도였다면 남남협력에서는 수평적 구도로서 행위주체 간 관계는 교류와 협력에 초점 을 두고 있다.

재원의 성격과 관련하여 남북협력에서는 공여주체가 재정적인 지원을 주로 전담함으로써 Top down 방식의 틀 내에서 조건부 지원이 이루어지는 경향을 보이고 있으나 남남협력에서는 행위주체자 간 재정적 혹은 이에 상당하는 역할을 공동으로 분담하는 것을 원칙으로 하고 있으며 비조건성 지원 이 이루어진다.

지원의 효과는 남북협력에서는 선진국의 전문 인력이 투입되어 이로 인해 행정비용이 차지하는 비 율이 높으나 남남협력에서는 개발도상국의 전문가가 직접 투입됨으로써 집행이 신속하게 이루어지 며 행정비용이 낮고 수혜자에 대한 직접적인 영향을 끼칠 수 있다. 그러나 전통공여국의 시각에서 남 남협력은 장학금 지급, 공동연수, 단기 전문가 파견, 세미나 등의 형태로 이루어지고 있어 성과관리를 위한 모니터링과 평가체제 구축의 필요성이 언급되고 있다.

\section{3. 남남협력 개념의 발전과정}

사회주의 진영이 무너지면서 '제 3세계'라는 용어가 함축하고 있는 논리적인 근거가 희박해진 것 처럼9) 북(North)과 남(South)의 개념, 이를 구분하는 기준의 모호성으로 인해 남남협력이라는 용 어자체에 대한 논란은 지속되어 왔다. '남(South)'은 '북(North)'과 대비되는 개념이며 월러스타인 (immanuel wallerstein)은 근대 자본주의 세계체제를 중심부(core)와 주변부(periphery)로 나누고 있는데 남(South)은 주변부, 빈곤, 저발전과 연관되고 있다.

남남협력은 2차 세계 대전 이후 발생한 반식민운동에서 기원하고 있다. 제 3세계 국가들에 의한 최 초 회의이며 이들 간의 결속을 상징하는 1955년 반둥회의(bandung conference), 1961년 비동맹운동 (non-aligned movement), 1964년 G-77의 설립 등을 통해 개발도상국들은 정치적인 자립과 경제 발전을 추구해 왔으며 선진국과의 관계에서 불평등을 개선하기 위한 방안을 모색해 왔다. 이러한 과 정에서 남남협력에 대한 관심이 확대되어 왔으며 남남협력은 정부와 공공기관 외에도 비정부 기구와 독립된 행위주체에 의해 이루어질 수 있다(Morais de Sá e Silva, 2009: 39).

9) 제 1 세계는 자본주의 진영, 제 2 세계는 사회주의 진영을 의미했으나 사회주의 진영이 무너지면서 제 3 세계라는 용 어의 논리적 근거가 희박해졌다. 그러나 오늘날 제 3세계는 2차 세계 대전 이후 새롭게 독립했으며 경제발전의 정 도가 낮은 국가를 의미하고 있다(박준영, 1997: 237). 
본 연구에서는 남남협력의 역사적인 발전시기를 세 단계로 구분하여 시기별 특성을 분석하고자 한 다(Morais de Sá e Silva, 2009: 39-51).

첫 번째 시기는 1949년부터 1979년까지이며 냉전 상황에서 개발도상국들의 자립과 정치적 강화 (self-reliance \& political strengthening)를 특징으로 언급할 수 있다. 특히 냉전으로 인해 정치 적인 동기가 강하게 작용하면서 남남협력은 개발도상국의 자조와 정치력 강화를 위한 수단으로 활용 되었다. 또한 중남미 학자들에 의해 주창된 종속이론(dependency theory)의 관점 ${ }^{10)}$ 에서 남남협력 은 불평등한 국제체제로부터 탈피하여 신국제경제질서(new international economic order, NIEO) 를 형성하기 위한 출구전략으로 고려되었다. 당시 신생독립국의 증가와 '일국일표(one country, one vote)'라는 유엔총회의 원칙에 따라 개발도상국들은 다자관계에서 집단적으로 행동을 할 수 있는 정치 적인 환경이 조성되었다. 한편, 경제 부문 뿐 아니라 사회분야에서 쿠바와 같은 국가는 혁명 이후 성 인문맹퇴치 운동을 적극적으로 추진하면서 의사와 교사 등 자국의 전문 인력을 모잠비크, 앙골라 등 동맹국으로 파견하여 정치적인 연대와 영향력을 강화하고자 하였다.

두 번째 시기는 냉전이후인 1980년부터 1988년으로 해체(demobilization)를 특징으로 하고 있으 며, 이는 개발도상국들의 동원력과 정치적인 협력이 부채위기와 구조조정으로 약화되었음을 의미하 고 있다. 또한 냉전의 종식이라는 국제정치 지형의 변화와 더불어 자유주의 진영과 공산주의 진영 사 이 '제 3세계'라는 용어에 내포되었던 중립적인 가치는 해체되었다.

세 번째 시기는 신자유주의 이후로서 개발도상국들은 이전 시기와는 다른 새로운 형태의 빈곤과 실업문제를 해결해야 하는 상황에 처하게 되었으며 선진국과의 관계에서 남남협력은 다시 부각되 었다.

이처럼 오늘날 남남협력은 냉전 당시의 정치적인 성격보다 국제체제의 변화와 외교정책에서 행위 주체 간 협력을 위한 주요한 전략으로 고려되고 있다. 또한 개발협력에서 남남협력은 정책과 프로그 램을 전달하기 위한 새로운 수단으로서 그 개념이 확대되고 있다.

10) 종속이론에 의하면 제 3세계의 정치, 경제적 문제와 남북문제는 종속이라는 구조적인 수준을 변수로 설명할 수 있 으며 후진국의 문제는 후진국만의 문제가 아닌 세계 전체의 문제이며, 이는 국제정치경제 질서가 불평등함을 보여 주고 있다(서울대학교, 2002: 365). 


\section{III. 새로운 글로벌 파트너십에 대한 재고: 쿠바와 아이티 사례를 중심으로}

본 연구에서는 새로운 글로벌 파트너십에 대해 재고하기 위한 사례로서 쿠바와 아이티의 남남협력 을 행위주체 간의 역할과 관계, 재원의 성격, 지원의 효과에 초점을 맞추어 분석하였다.

본 연구에서 라틴아메리카 국가를 사례로 다루는 배경에는 아이티를 제외한 모든 라틴아메리카 국 가들이 중소득국(middle income countries, MICs)에 속하고 있으며 이들은 수원국에서 신흥공여국 으로 전환하고 있기 때문이다. 따라서 미국, 독일, 스페인, 일본 등 DAC 주요 공여국들은 라틴아메리 카 국가들에 대한 정책방향을 전환하고 있다. 또한 라틴아메리카는 지리적인 근접성, 정치, 경제, 사 회적인 체제에서의 공유성을 바탕으로 이들 간 남남협력을 확대하고 있다.

아래 표에서 보는 것처럼, 라틴아메리카 남남협력에서 주요 공여국은 브라질, 아르헨티나, 베네 수엘라, 멕시코, 칠레, 쿠바, 콜롬비아 등이며 이들은 주로 중미, 카리브, 남미 등 역내 지역 국가들

〈표 2〉라틴아메리카의 남남협력

\begin{tabular}{|c|c|c|}
\hline 남남협력 공여국 & 남남협력의 대륙별 배분 & 남남협력 배분지역의 특성 \\
\hline 브라질 & $\begin{array}{l}\text { 아프리카(52\%), 중남미와 카리브(35\%), } \\
\text { 아시아(10\%) }\end{array}$ & $\begin{array}{l}\text { 역내 및 역외(포루투갈 어를 사용하는 } \\
\text { 아프리카, 동티모르) }\end{array}$ \\
\hline 아르헨티나 & $\begin{array}{l}\text { 중미와 카리브(57\%), 남미(38\%), } \\
\text { 동유럽(2\%), 북아프리카(2\%) }\end{array}$ & 역내(중미와 카리브, 남미접경) \\
\hline 베네수엘라 & $\begin{array}{l}\text { 중미 및 카리브 } \\
\text { 남미 }\end{array}$ & 역내(ALBA회원국) \\
\hline 멕시코 & $\begin{array}{l}\text { 중미 및 카리브 } \\
\text { 남미 }\end{array}$ & 역내 \\
\hline 칠레 & $\begin{array}{l}\text { 안데스 지역(64\%) } \\
\text { 중미(23\%) }\end{array}$ & 하위지역 \\
\hline 쿠바 & $\begin{array}{l}\text { 중미 및 카리브 } \\
\text { 남미 } \\
\text { 아프리카 }\end{array}$ & 하위지역(카리브) \\
\hline 콜롬비아 & $\begin{array}{l}\text { 접경지역 및 카리브 } \\
\text { 남미 }\end{array}$ & 하위지역 \\
\hline
\end{tabular}

출처: Rojas(2011) 
과 미주대륙을 위한 볼리바르 동맹(Alianza Bolivariana para los Pueblos de Nuestra América, $\mathrm{ALBA}$ )과 같은 지역통합체 회원국을 중심으로 지원하고 있다. 이외에도 브라질, 아르헨티나, 쿠바 등 은 역내 국가들 뿐 아니라 자국과 동일한 언어권이거나 정치, 역사적인 연대감을 토대로 제 3 세계로 분류할 수 있는 아프리카와 같은 역외 국가들을 지원하였다.

제I장

1960년-1980년대 개발도상국의 반식민운동, 정치적인 자립, 경제발전 추구라는 국제체제의 변 화 흐름이 반영되어 쿠바의 남남협력에는 정치적인 성격이 내포되었으며 혁명을 경험했던 알제리, 앙 골라, 에티오피아, 니카라과 등에 쿠바의 전문 인력들이 파견되어 이들 국가를 지원하였다(Marimón Torres, Nestor \& Martínez Cruz, Evelyn, 2011: 385).

쿠바 교육제도의 특성은 학교와 지역공동체에 초점을 두고 있으며 교사와 의사들은 학교와 지역공 동체를 연결하는 매개체로서 역할하고 있다(정진상, 2011: 367).

1961년부터 시작된 성인문맹퇴치 운동은 쿠바의 대표적인 교육정책이며 교육을 받은 교사와 학생 등 글을 읽고 쓸 수 있는 사람들은 농촌과 산간벽지에 직접 파견되어 지역주민과 일대일 방식의 접촉 을 통해 지식을 전파하는 역할을 하였다. 이러한 방식을 통해 지역공동체 주민들과 형성된 유대관계 와 사회적 관계망은 사회통합에 중요한 기여를 했으며 쿠바 교육체제의 근간이 되었다(정진상, 2011: 378-379). 또한 문맹퇴치운동은 일회성으로 끝나지 않고 공식초등학교 과정과 중등학교 과정 등 성 인교육 프로그램으로 이어져 지속적으로 운영되었다(정진상, 2011: 379).

이러한 쿠바 교육정책의 이념과 특성이 반영되어 2001년에 만들어진 '나는 할 수 있다(Yo, sí puedo)'라는 문맹퇴치 프로그램은 조력자(facilitator)를 중심으로 글을 읽을 수 있는 사람들과 그렇 지 못한 사람들 간 협력체계가 구축되어 교육 장소에 구애 받지 않고 어디에서든지 프로그램을 진행

11) 1961년 까스뜨로는 교육의 해(Year of Education)를 선포하고 약 9개월 동안 문맹퇴치운동을 실시했으며 그 결과 문맹률은 21\%에서 3.9\%로 떨어졌다(정진상, 2011: 378-379). 
할 수 있도록 기획되어 있다(SEGIB, 2011: 121). 또한 초기 프로그램을 이수한 사람들은 '이제 읽을 수 있다(Ya puedo leer)', '나는 계속할 수 있다(Yo, sí puedo seguir)'라는 단계별 과정에서 학습을 심화할 수 있다.

이외에도 교육방법론적 측면에서 쿠바의 정책은 협력을 원하는 지역의 정치, 경제, 사회, 문화, 제 도적인 배경과 부합할 수 있도록 기획되어 있으며 쿠바 교사는 직접적으로 정책을 수행하기보다는 교 육방법론을 현지의 조력자에게 전달하는 역할을 담당하고 있다(SEGIB, 2011: 121).

따라서 라틴아메리카 카리브 교육연구소(Instituto Pedagógico Latinoamericano y Caribeño, IPLAC)와 쿠바 교육부는 이러한 교육방법론을 라틴아메리카, 아프리카, 오세아니아 지역 28개국에 보급하였다(SEGIB, 2011: 121).

라틴아메리카의 남남협력 통계를 정리하여 매년 보고서로 발간하고 있는 이베로아메리카 사무국 (Secretaría General Iberoamericana, SEGIB)은 니카라과와 파나마에서 이루어진 정책전수와 체계 화 과정을 성공적인 사례로 언급하고 있다(SEGIB, 2011: 121-122).

니카라과는 2002년 자국의 문맹률을 낮추기 위해 쿠바의 교육방법론을 활용하기 시작했으며 2007년 쿠바의 정책은 니카라과의 공공정책으로 도입되면서 본격적인 문맹퇴치 운동이 시작되었다. 이후 전국 규모로'이제 읽을 수 있다(Ya puedo leer)','나는 계속할 수 있다(Yo, sí puedo seguir)'와 같은 심화과정이 추진되었다. 특히 양국은 ALBA라는 지역협력체의 틀 내에서 남남협력을 추진했으 며 이를 통해 협력관계를 공고화하였다.

파나마는 사회개발부에서 추진한 자국의 빈곤퇴치 프로그램에 쿠바의 교육방법론을 적용하고 쿠바 로부터 기술적인 지원을 받았다. 특히 농촌과 산간벽지 등 교육 접근성이 떨어지는 지역에 교사들을 직접 파견하여 일대일 방식의 접촉을 통해 지식을 전파하는 쿠바 교육의 방법론적인 측면을 적용하였 다. 2007년 2개 지역으로 시작되었으나 이후 9개 지역과 원주민 거주 지역까지 보급되었다.

한편, 1990 년대 보건 분야에서 쿠바의 종합 건강프로그램이 중미, 카리브 지역을 시작으로 아프 리카와 태평양 국가로 확대되었으며 의료부대(Brigada Médica)가 수원국의 의료 인력이 없거나 의 료서비스 접근성이 떨어지는 지역에 파견되었다. 또한 쿠바정부는 사업의 연속성과 지속가능성을 위 해 의료학교(la escuela latinoamericana de medicina)를 설립하고 의료부대원들의 기본적인 생활 이 충족될 수 있도록 경제적으로 지원하였다(Marimón Torres, Nestor \& Martínez Cruz, Evelyn, 2011: 386). 따라서 1963년부터 2008년까지 134,849 명의 전문 인력이 108 개국에 파견되었으며 대륙 별로는 아프리카 38 개국에 45,488 명, 라틴아메리카 39 개국에 79,717 명, 유럽, 아시아태평양 및 중동 지역 31개국에 9,644명이 참여하였다(Marimón Torres, Nestor \& Martónez Cruz, Evelyn, 2011: 
$384-385)$

2003년에 시작한 미시온 바리오 아덴트로(Misión Barrio Adentro)는 베네수엘라 우고차베스 (Hugo Chávez) 대통령에 의해 추진되었던 사회정책이며 본 정책의 추진과정에서 쿠바의 의료 인력 이 활용되었다. 정책의 내용은 일명 '바리오(Barrio)'라고 불리 우는 낙후된 지역에 거주하는 베네수엘 라 주민을 대상으로 1 차 진료 위주의 의료서비스 시스템을 구축하는 것이다. ${ }^{12)}$ 베네수엘라 정부는 이 정책을 $2,3,4$ 단계로 발전시켜 가면서 종합 진료 센터, 재활 및 요양센터 뿐 아니라 어린이 심장병원 과 전문적인 진료센터 설립으로 확대하였다.

제I장

\section{2. 아이티에 대한 남남협력}

아이티는 라틴아메리카에서 유일한 저소득국이며 1990년대 국제사회로부터 40억불 이상의 지원 을 받았으나 인간개발지수(human development indice, HDI)는 150위에서 154위로 하락하였다 (Lengyel, 2011: 52-53). 2000년대 국제사회의 아이티에 대한 지원은 감소했으나 2004년 아이티 정부에서 유엔 평화유지군을 요청했으며 이중 절반이상은 라틴아메리카인들로 구성되었다(Lengyel, 2011: 53-54).

아이티는 전통적인 공여국과 새롭게 출현한 신흥공여국들로부터 지원받고 있으며 이처럼 오랜 기 간 동안 수원국으로 분류되어 왔다. 특히 라틴아메리카의 $\mathrm{ABC}$ 국가라고 불리 우는 아르헨티나, 브라 질, 칠레는 아이티의 주요 공여국으로 역할했으며 이들은 유엔 평화유지군의 일원으로 참여했을 뿐 아니라 농업, 교육, 보건, 환경부문에서 다양한 사업을 추진하였다. 또한 $\mathrm{ABC}$ 국가 간의 원조조화와 아이티 정부와의 협력을 위한 공여국 협의체 뿐 아니라 G-10회의 내 상설의석을 통해 전통공여국과 의 원조 협의 체제를 구축하였다(Lengyel, 2011: 54). 2010년 지진발생 이후 $\mathrm{ABC}$ 국가의 지원은 확 대되었다.

아래 표에서 보는 것처럼 아이티를 지원하는 국가들은 미국, 캐나다, 프랑스, 스페인 등 DAC회원 국, 라틴아메리카 $\mathrm{ABC}$ 국가, 기타 공여국으로 분류할 수 있다.

$\mathrm{ABC}$ 국가 이외에 쿠바와 베네수엘라는 유엔 평화유지군으로 참여하지 않았으나 쿠바는 500명이상 의 전문 의료 인력을 아이티에 파견했으며 문맹퇴치 운동을 지원하였다(Lengyel, 2011: 57). 베네수 엘라는 하루 6,500 배럴의 석유를 아이티에 지원했으며 카리브석유협력기구(petrocaribe)의 틀 내에 서 디젤과 가스 등을 시장가격 이하로 공급하는 등 에너지 분야를 지원하였다(Lengyel, 2011: 57).

12) Wikipeia, "Misión Barrio Adentro", https://es.wikipedia.org/wiki/Misi\%C3\%B3n_Barrio_Adentro(검색일: 2015 년 9월 1일) 
〈표 3〉 아이티의 지원현황(2004-2008)

\begin{tabular}{|c|c|c|c|}
\hline & DAC공여국 & $\begin{array}{c}\text { 중소득국 } \\
\text { (유엔 평화유지군 참가국) }\end{array}$ & 기타 공여국 \\
\hline 국가 & $\begin{array}{c}\text { 미국, 캐나다, 프랑스, } \\
\text { 스페인 등 }\end{array}$ & $\begin{array}{c}\text { 아르헨티나, 브라질, } \\
\text { 칠레(ABC) }\end{array}$ & 쿠바, 베네수엘라 \\
\hline $\begin{array}{c}\text { 원조공여국 } \\
\text { 협의체 }\end{array}$ & 공여국 간 회의 & $\begin{array}{c}\text { 2X4, 2X6, } 2 \times 9 \\
\text { (아이티 정부와의 } \\
\text { 정치적 협의체) } \\
\text { G-10회의 내 의석 }\end{array}$ & $\begin{array}{c}\text { 페트로카리브(Petrocaribe)와 } \\
\text { 기타 }\end{array}$ \\
\hline 지원분야 & $\begin{array}{c}\text { 제도적인 역량강화, } \\
\text { 치안 }\end{array}$ & $\begin{array}{c}\text { 식량안보, 교육, 보건, } \\
\text { 환경, 에너지 }\end{array}$ & 에너지, 보건 \\
\hline 협력구도 & 남북협력 & 남남협력 & 남남협력 \\
\hline
\end{tabular}

출처: Lengyel(2011)

라틴아메리카 국가들은 미국, 유럽연합, 캐나다와 같은 전통공여국의 지원규모에 미치지 못했으나 아이티 정부의 수요와 요청을 직접적으로 반영하여 다양한 사회부문을 지원하였다. 전통공여국들의 주된 지원 분야는 제도적인 역량강화와 치안분야였다면 라틴아메리카 국가들은 식량안보, 교육, 보 건, 에너지 분야에 지원하였다. 라틴아메리카 국가들의 지원형태는 기술협력으로 비조건성 지원이 주 를 이루었다는 특징을 보이고 있으며 아이티 정부와의 협력을 위해 전통공여국과의 정치적인 협의체 를 구축하고 이를 활성화하려는 움직임을 보였다.

이와 같이 오늘날 남남협력은 과거 개발도상국들에 의해 주창되었던 정치적인 성격의 동맹과 협력 이라는 의미로부터 개발협력에서 양자와 다자차원의 공여기관에 의해 새로운 전달과 협력수단으로서 그 개념이 확대되고 있다.

쿠바와 아이티의 사례에서처럼 남남협력에서 행위주체는 개발도상국, 중소득국, 신흥공여국이며 이들 간의 관계는 상호협력과 교류라는 원칙에 따라 수평적인 성격의 구도를 형성하고 있다. 이처럼 행위주체 간 수평적인 틀 내에서 공여기관은 수원국을 대상으로 일방적으로 지원하는 적극적인 주체 이기보다는 성공적인 정책전수와 전문 인력파견 등을 지원하고 있다. 이러한 측면에서 남남협력은 정 책, 제도, 지식의 전달을 위한 수단으로 정의할 수 있다.

정책 전수의 과정을 본다면 초기 시범지역을 중심으로 이를 발전시켜 확대, 심화하고 있다. 이외 에도 공여국이 파견한 전문 인력은 수원국에서 직접적으로 정책을 수행하는 역할을 하기 보다는 현지 조력자에게 지식을 전달하며 이들에게 학습의 기회를 제공하고 있다. 또한 전수받은 정책은 수원국의 
정치, 경제, 사회, 문화적 맥락과 여건에 부합될 수 있도록 수정과정을 거치고 있다. 그 후 조력자는 자국의 수혜계층을 대상으로 정책을 직접적으로 수행하는 역할을 하고 있는데 이러한 이유로 행정비 용이 낮아지며 신속하게 이루어질 수 있고 수혜자에게 직접적인 영향을 끼칠 수 있다.

이상과 같이 쿠바의 교육정책은 전 세계 국가의 정책수립과 실시과정에 영향을 끼쳤으며 각 국가 들은 쿠바로부터 전수받은 정책을 $2,3,4$ 단계로 발전시켜 지속적으로 추진하였다.

남남협력의 효과와 관련하여 미비한 모니터링과 평가체제 등 단점에 대해 언급되어 왔으나 위의 사례에서처럼 남남협력은 행위주체간의 '관계(relationship)'와 '과정(process)'를 중시하고 있으며 이 러한 측면에서 기존 공여국들이 협력 사업에서 강조하고 있는 결과와 영향력 관련한 지표들에 대해 성찰하는 것이 필요하다.

\section{IV. 결론}

세계가 단일의 윤리적 공동체로 구성되어 있으며 모든 개인은 동등한 윤리적 가치를 보유하며 국적, 지역, 인종에 관계없이 모든 사람들에 대한 의무가 있다는 신념을 반영하고 있는 세계주의 (cosmopolitanism)로부터 세계배분의 정의(distributive justice)가 정립되었고 이러한 개념으로부터 오늘날 선진국과 빈곤국 사이의 적절한 재분배의 필요성이 강조되어 왔다(Heywood, 2013: 23).

이러한 이념적인 기반을 토대로 개발협력 체제는 국제적인 환경의 변화와 더불어 발전해 왔으며 특히 오늘날 다양한 행위주체의 등장으로 인해 개발협력의 새로운 지원방식에 대한 논의가 확대되어 왔다.

따라서 본 연구에서는 행위주체, 행위주체간의 협력구도, 이들 간의 형성되어 있는 포괄적인 파트 너십 관계에 초점을 두고 남남협력의 개념을 재정립하고 쿠바와 아이티의 남남협력 사례를 분석하였 다. 이처럼 남남협력 사례분석을 통해 도출한 한국에 대한 정책적인 시사점은 다음과 같다.

첫째, 우리는 개발협력에서 적극적인 행위주체자로서 역할하기보다는 조력자로서의 역할을 강화 할 필요가 있다. 쿠바가 다른 개발도상국을 대상으로 지원해왔던 성공적인 정책의 전달과정에서 쿠바 의 전문 인력들은 수혜자를 대상으로 정책을 직접적으로 실시하기보다는 지역의 조력자에게 전달하 는 역할을 하고 있다. 따라서 우리는 남남협력에서 개발도상국, 전통공여국, 신흥공여국이라는 행위 주체의 개념, 성격과 역할 등 원론적이며 기술적인 문제에 집착하기보다는 개발협력 자체를 남남협력 의 틀로부터 발전된 개념으로 고려할 필요가 있다. 이와 더불어 수원국에 대한 자주권을 존중하고 이 
들의 실질적인 역할과 적극적인 참여가 확대될 수 있는 운영 체계를 구축해야 한다.

둘째, 남남협력은 수원국의 입장에서 유용하다고 볼 수 있다. 반면 남남협력은 공여국이 제시하고 있는 원조효과성과 관련된 지표를 용이하게 검증할 수 없다는 단점이 있다. 그러나 실제로 쿠바가 다 른 국가에 전수했던 정책 모델들은 수원국 정책의 일부로서 추진되어 왔으며 지속적으로 확대, 발전 되었다. 이러한 측면에서 남남협력은 개도국 간 성공사례와 경험을 공유하는 과정으로서 탄력성이 있 고 수원국의 환경과 현실에 적합하다고 볼 수 있다.

이와 같이 남남협력은 수원국과 공여국 간의 규범적이고 위계적인 관계를 극복할 수 있는 효과 적인 방안으로 볼 수 있다. 특히, 남남협력이 Post-2015 체제에서 강조하는 역량개발(capacity building)을 위한 효율적인 수단이라는 점을 고려한다면, 향후 남남협력 사례에 대해 더 많은 분석과 연구가 필요하며 이를 활용하여 개발협력을 지원할 수 있는 다양한 방안을 모색해야 한다.

마지막으로 남남협력을 활용한 지원을 확대하기 위해서는 정치적인 의지가 필요하다. 이와 관련하 여 향후 우리가 지향해야 할 개발협력의 개념을 재정립하고 새로운 정책방향을 재고할 필요가 있다. 개발협력을 “문화적 공유의 지평”으로 인식하는 것처럼 오늘날 개발협력은 국가중심이 아닌 다차원적 인 수준에서 출현한 다양한 행위주체 간의 협력, 국제적인 이동과 교류의 수단이 될 수 있으며 세계주 의를 활성화할 수 있다. 


\section{〈참고문헌〉}

\section{국내문헌}

경희대학교 산학협력단, 국제학연구원, 2015 출간예정.『중남미지역 삼각협력 발전방안 연

구』. 성남: 한국국제협력단.

박준영. 1997.『국제정치학』. 서울: 박영사.

서울대학교. 2002.『정치학의 이해』. 서울: 박영사.

이현주. 2009. $\mathrm{KOICA}$ 사업의 삼각협력 추진방안』. 성남: 한국국제협력단.

2015. “새로운 ODA행위주체와 지원방식에 대한 재고, 중남미 국가의 사례를 중심

으로"『국제정치연구』. 제18집 1호. 대구: 동아시아국제정치학회. pp. 103-122.

. 2014. "Mexico y Corea del Sur en el marco de la cooperaciónSur-Sur y

Triangular"『스페인어문학』. 제70호. 서울: 한국스페인어문학회. pp. 156-187.

정상희. 2013. “라틴아메리카의 남남협력과 삼각협력 현황 및 우리의 활용 방안” 『이베로아메 리카』Vol.15(1). 부산: 부산외국어대학교 중남미지역원. pp. 79-115.

정지원 외. 2011. 『국제사회의 남남협력 현황과 우리의 추진방안』. 서울: 대외경제 정책연구원. 정진상. 2011. “쿠바의 학교와 지역공동체”『경제와 사회』봄호(제 89호). 서울: 비판사회학

회. pp. 367-398.

\section{국외문헌}

Chisholm, Linda. 2009. "Introduction: Rhetoric, Realities, and Reasons" pp.1-13 in América Latina y el Caribe: Nuevas froams de Cooperación Sur-Sur.

Lengyel, Miguel. 2011. “El desafío de la Cooperación Sur-Sur en América Latina. El caso del ABC en Haiti” pp.49-67 in América Latina yel Caribe: Nuevas froams de Cooperación Sur-Sur.

Marimón Torres, Nestor \& Martínez Cruz, Evelyn, 2011. "Experiencia Cubana en Cooperación Sur-Sur", Revista Cubana de Salud Pública 37(4): 380-393. 
Morais de Sá e Silva, Michelle. 2009. "South-South Cooperation, Past and Present Conceptualization and Practice" pp.39-59 in South-South Cooperation in Education \& Development, edited by Linda Chisholm \& Gita Steiner-Khamsi. New York, Teachers College, Columbia University.

Rojas Aravena, Francisco. 2011. "Cooperación Sur-Sur y cooperación triangular: nuevas formas de asociación y vinculación” pp.19-47 in América Latina y el Caribe: Nuevas froams de Cooperación Sur-Sur.

Samoff, Joel. 2009. “Foreign Aid to Education, Managing Global Tranfers and Exchanges" pp.123-156 in América Latina y el Caribe: Nuevas froams de Cooperación Sur-Sur.

Secretaría General Iberoamericana(SEGIB). 2011. Informe de la Cooperación SurSur en Iberoamérica 2011, Madrid: SEGIB.

\section{번역서}

Heywood, Andrew. 2013. 『국제관계와 세계정치』김계동 역. 서울: 명인문화사.

Margaret P. Karns and Karen A. Mingst. 2011. 『국제기구의 이해, 글로벌 거버넌스의 정 치와 과정』김계동 외 (역). 서울: 명인문화사.

\section{웹사이트}

OECD DAC, http://www.oecd.org/dac/45361474.pdf(검색일: 2015. 8. 31.)

Runde, Daniel, "The new role for non-state actors in development: implications for communications officers, http://www. oecd.org/development/pgd/41769582. $\operatorname{pdf}$ (검색일: 2015. 8. 31.)

Wikipeia, "Misión Barrio Adentro", https://es.wikipedia.org/wiki/Misi\%C3\%B3n_ Barrio_Adentro(검색일: 2015년 9월 1일) 